\title{
Eating the audience
}

\author{
Bernadette Hince ${ }^{1}$
}

One hundred and ten years ago, a Scot in full Highland dress walked down a gangway and onto the ice of the Weddell Sea in Antarctica. It was a most improbable sight, and the expedition's leader captured it in photographs.

It was the time of the heroic era of intensive Antarctic exploration, a period which began late in the 19th century and stretched some distance into the early 20 th century. ${ }^{2}$ During this time, the man who was to lead the piper's expedition, William Speirs Bruce (Figure 1), made his first trip to Antarctica as a member of the Dundee Whaling Expedition of 1892-93. It was a relatively short voyage from Scotland, considering the distance of its destination, and Bruce found it frustrating from a natural science point of view. But it made him a polar man for life. 'I am burning to be off again anywhere, but particularly to the far south where I believe there is a vast sphere for research', he wrote. ${ }^{3}$

Three years later, in June 1896, he travelled north as a naturalist on the JacksonHarmsworth Arctic expedition. Fridtjof Nansen and Hjalmar Johansen were at the expedition's Cape Flora base when he arrived. It was to be the first of many trips Bruce made to the Arctic.

\section{With 'Scotland' emblazoned on its flag}

Bruce's scientific work in both polar regions qualified him better than most to apply as a senior scientific member of Scott's British National Antarctic Expedition on the Discovery, which was leaving England in 1901. His request eventually led only to an offer of a junior appointment which he fairly naturally declined.

After failing to join Scott's expedition at a senior level, he organised his own expedition. Though London-born, Bruce was passionately Scottish, and the crew and scientists of his Scottish National Antarctic Expedition of 1902-04 were almost all Scottish. ${ }^{4}$ He had met Major Andrew Coats in the Arctic during the late 1890s. Andrew and James Coats backed the expedition financially. ${ }^{5}$

\footnotetext{
1 Dr Bernadette Hince, Visiting Fellow, Australian National Dictionary Centre, The Australian National University, Canberra ACT 0200, coldwords@gmail.com.

2 Perhaps to 1913-14, perhaps into the 1920s - see Pharaoh (this volume).

3 Bruce ms, quoted in Peter Speak (2004) 'Bruce, William Speirs (1867-1921)', Oxford Dictionary of National Biography. Oxford University Press, www.oxforddnb.com.virtual.anu.edu.au/view/article/32137, accessed 27 July 2014.

4 Speak (2004) 'Bruce, William Speirs (1867-1921)', accessed 28 July 2014.

5 Speak (2004) 'Bruce, William Speirs (1867-1921)', accessed 28 July 2014.
} 


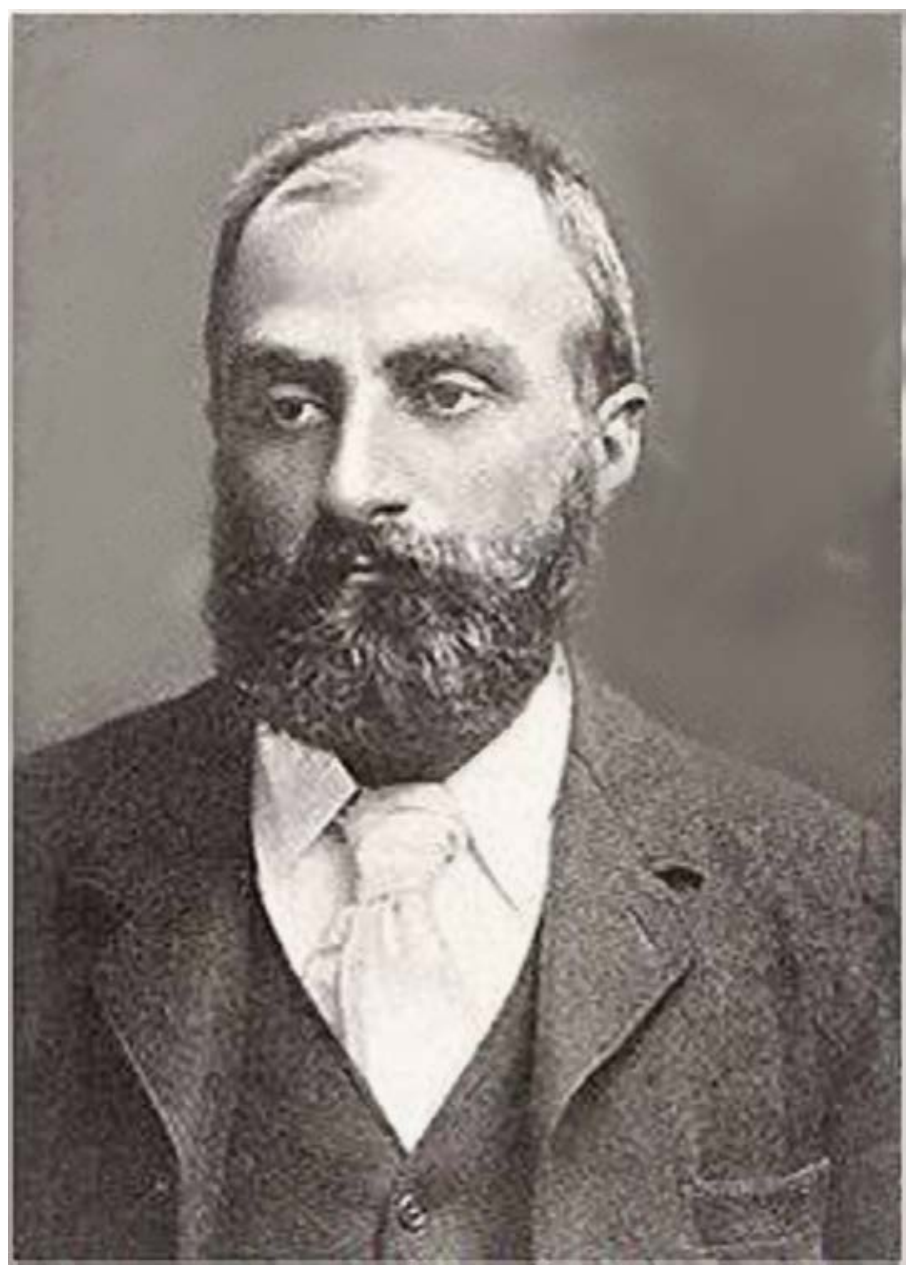

\section{Figure 1. William Speirs Bruce (1867-1921), leader of the Scottish National Antarctic Expedition.}

Source: Reproduced with permission of the Glasgow Digital Library, University of Strathclyde.

Bruce's ship the Scotia sailed south from Scotland in November 1902. In March 1903 the ship was frozen in at what became known as Scotia Bay on Laurie Island. Here the men began eight months of ice-bound life on board. Scientifically, the expedition's legacy was significant. Ashore, they established a meteorological station, Omond House, now the oldest working observatory in Antarctica. (When the Scotia was freed by the ice, Bruce sailed from the Antarctic to Buenos Aires in December 1903 and persuaded the Argentinians to take over the meteorological station. ${ }^{6}$ )

6 William James Mills (ca 2003) Entry on William Speirs Bruce (1867-1921) in Exploring polar frontiers A-L: vol 1, Oxford, Santa Barbara CA, p. 104. 
In their winter 'beset' in the ice, the young chief engineer of the ship, Allan Ramsay, had died of heart disease. On a crisp Antarctic day, Kerr led the coffinbearers across the ice to shore, playing a traditional Scottish folk tune often chosen as a lament, 'The Flowers of the Forest' ${ }^{7}$ It is easy to imagine the emotions of the men, so far from Scotland, as they farewelled their dead companion.

Late in the southern autumn of 1903-04 the steam yacht Scotia was again briefly beset in the pack ice of the Weddell Sea. During the shorter besetment, one evening in March 1904 Kerr, in highland dress with his pipes, was on deck. His kilt swirled about him as he walked down the ship's gangway. Men were working on the sea ice around the frozen-in ship, and shovelling snow into a large pan for the ship's water supplies, or catching emperor penguins (numerous on the ice that day) which they skinned, dissected, and used for food. ${ }^{8}$

Kerr had warmed up his pipes in the comfort of shelter below decks. When he stepped onto the ice he walked briskly out away from the ship and stopped near one of penguins. When he began to play, the penguin looked up with apparent curiosity. Bruce photographed the striking sight, recording in the ship's log, 'After dinner I spent a considerable time, as it was sunny, photographing the piper, the ship and an Emperor Penguin, and a football scene'. ${ }^{9}$

The photographs (see Figure 2) provided what became the most recognisable scene of the expedition (one later featured on a British Antarctic Survey stamp). ${ }^{10}$ As some of them show, Kerr was playing to a penguin which had in fact been leg-roped to a small pan full of ice.

Despite the rope, an emperor penguin could scarcely have been detained if it had wanted to leave. Expedition men and ship crews who handled them noted that the birds are fast and powerful, even on the ice.

'It was just all that one man could do to lead one up to the ship: with their beaks they bit fairly hard, and with their long flipper-like wings could hit out decidedly hard', wrote the Scotia's doctor and geologist, James Harvey. ${ }^{11}$

\footnotetext{
7 RC Mossman, JH Harvey Pirie and RN Rudmose Brown (1906) The voyage of the 'Scotia' (originally published by William Blackwood and Sons, Edinburgh). Australian National University Press facsimile, Canberra 1978, p. 153.

8 Brian Gunning (2007) 'The Piper and the Penguin'. Scotch Circle [newsletter of the Canberra and District Branch, Royal Scottish Country Dance Society] 27(2) May: unpaginated.

9 Gunning (2007) 'The Piper and the Penguin'.

10 http://bit.ly/lvtjPRE, accessed 30 August 2014.

11 Mossman et al (1906) The voyage of the 'Scotia', p. 241.
} 


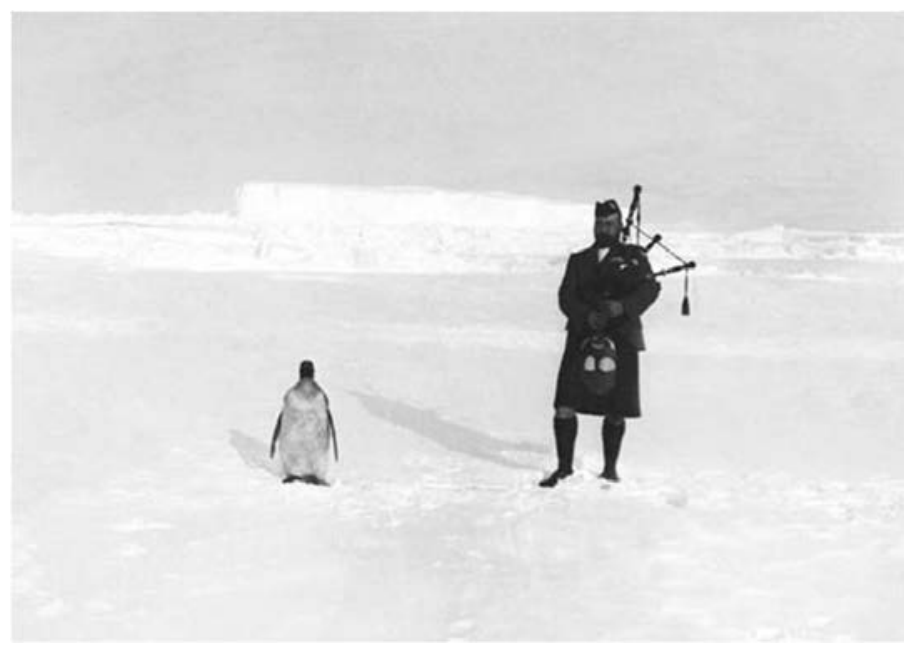

Figure 2. Gilbert Kerr playing his bagpipes to an emperor penguin, Scotia expedition, March 1904.

Source: Reproduced with the permission of the Royal Scottish Geographical Society.

Men on other expeditions had similar experiences of the unbiddability of penguins. On one Antarctic morning in January 1914 at Commonwealth Bay, 26-year-old Peter Goddard (the Aurora's second steward) went out with the second engineer, chasing emperor penguins. Between them the two men caught and killed one animal. Goddard knocked down another bird three times, but it still escaped him and made the safety of the water. 'Emperor Penguins are fine big birds about 3ft 6 inches high and very broad', Goddard wrote ruefully in his diary. ${ }^{12}$

Standing penguins can drop onto the ice and toboggan swiftly across it, using their flippers to propel themselves. The ability to do this, combined with their considerable weight (up to $35 \mathrm{~kg}$ ) and energetic reactions to handling, make it unlikely that penguins could have been forced to stand anywhere at all, whether near the piper or not.

But penguins are also by nature inquisitive. As visitors to Antarctica discover, penguins will approach someone who sits quietly. Sometimes, they come so close that they are too close to be photographed.

A century after Kerr played his pipes for the penguin, geographer Innes Keighren described the incident as 'a frivolous and impromptu experiment'. ${ }^{13}$ It seems

12 Patrick G Quilty and Peter H Goddard (2004) 'The lower deck on Aurora: H.V. Goddard's diary, 1913-14'. Polar Record 40 (214): 193-203, p. 201.

13 Innes M Keighren (2003) 'A Scot of the Antarctic: the reception and commemoration of William Speirs Bruce'. MSc thesis, Geography Institute, University of Edinburgh, available at era.lib.ed.ac.uk/ 
more likely that Bruce anticipated — if not engineered - the scene of Kerr, his pipes and the penguin. Bruce had been in Antarctica before and had observed penguins before. He had scientific training. And he was the leader of a Scottish expedition, with explicitly nationalist aims for it.

He had hired Kerr to maintain morale during the voyage, as well as serving as a laboratory assistant. There were few ways in which he could better have reinforced the expedition's Scottish flavour than by taking a piper. ${ }^{14}$

Science was the talisman of the Expedition [he wrote] but 'Scotland' was emblazoned on its flag. It may be that in endeavouring to serve humanity by adding another link to the golden chain of science, we have also shown that the nationality of Scotland is a power that must be reckoned with. ${ }^{15}$

The presence of bagpipes neatly satisfied Bruce's nationalist ambitions. No single entity is more closely tied to Antarctica (even when not leg-roped to it) than a penguin. Bruce would surely have delighted in using the typically Scottish pipes when photographing piper Kerr with that most overused of Antarctic symbols, the penguin.

James Harvey Pirie suggested another motive for the spectacle. It was, he said, an experiment designed to test the effect of music on penguins. Did the penguins like the pipes? Kerr played marches, reels and laments without apparent effect, said Pirie - there was 'only sleepy indifference'. ${ }^{16}$

\section{Other penguin encounters with music}

There were other orchestrated encounters between penguins and music in Antarctica during the heroic era. Two of these occurred on Shackleton's Imperial Trans-Antarctic Expedition of 1914-17. In the first incident, three Adelie penguins approached meteorologist Leonard Hussey while he was playing a banjo. Shackleton wrote that:

The solemn-looking little birds appeared to appreciate 'It's a Long Way to Tipperary', but they fled in horror when Hussey treated them to a

bitstream/1842/890/1/Keighren.pdf, accessed 18 November 2013, p. 83.

14 William James Mills (ca 2003) Entry on William Speirs Bruce (1867-1921). In Exploring polar frontiers

$A-L$ : vol 1, Oxford, Santa Barbara CA, p. 103.

15 William Speirs Bruce (1906) in Mossman et al. The voyage of the 'Scotia', p. viii.

16 Pirie in Mossman et al. (1906) The voyage of the 'Scotia', p. 241. 
little of the music that comes from Scotland. The shouts of laughter from the ship added to their dismay, and they made off as fast as their short legs would carry them. ${ }^{17}$

The second occasion reflects the polarised opinions that bagpipes can so easily produce. When Scottish biologist Robert Clark 'endeavoured to entertain our little visitors with melodies of his native highlands', expedition photographer Frank Hurley later wrote, it was unsuccessful. 'His amiable intentions failed', said Hurley, 'for when the penguins heard the bagpipes, they fled in terror and plunged back into the sea'. ${ }^{18}$

Much later, in the mid-1950s, a visitor to subantarctic îles Kerguelen played an accordion to a group of penguins. The doctor at the French base on the island, Andre Migot, interpreted the penguins' reaction as positive. Though the choice of instrument was apt on a French island, the visitor was in fact an Australian, Phillip Law. Migot wrote:

It is known that they [penguins] are very fond of music. To prove it to us Dr Law fetched his accordion and began to play 'The Dead Leaves', one of his favourite songs. There was no doubt that the penguins were interested; they stretched out their necks and turned this heads on one side as if trying to hear better. ${ }^{19}$

These incidents are so few and so lacking in any comparability that we can really only guess at any reaction of penguins to bagpipes and other musical instruments. Observed behaviour seems to show no consistency at all - in Kerr's there is apparent indifference, in Law's curiosity, in Hussey's and Clark's, antipathy.

\section{The enduring image}

The Scotia returned to Scotland in 1904 with extensive scientific collections which became the basis of the Scottish Oceanographical Laboratory Bruce founded in Edinburgh in 1907. He published seven volumes of scientific reports from the expedition between then and 1919. After his death in 1921, his ashes were scattered off South Georgia in accord with his wishes. ${ }^{20}$

17 Ernest Shackleton (1919) South! The story of Shackleton's Last Expedition 1914-1917. Century Publishing, London, available at www.gutenberg.org/files/5199/5199-h/5199-h.htm, accessed 27 February 2012, no pagination.

18 Frank Hurley (1948) Shackleton's argonauts. Angus and Robertson, Sydney, p. 38.

19 Andre Migot (1956) The lonely South. Rupert Hart-Davis, London, p. 177.

20 Speak (2004) ‘Bruce, William Speirs (1867-1921)’, accessed 27 July 2014. 
More than a century after Bruce's expedition, the image of piper and penguin still has a modest but palpable life of its own in music and in literature. Scottish composer Roy Goldring used the name 'The Piper and the Penguin' for one of the dances of his Scotia Suite, which commemorated the centenary of the expedition. (The dance was performed in Canberra as an introduction to this paper in 2011 - see below.)

New Zealand writer Laurence Fearnley used the same title for a short story which centres around a photograph of the piper Kerr:

Kathleen looked at the photograph once more before fixing it to the fridge door by a plastic-coated magnet. She couldn't imagine the playing of the bagpipes in such a cold climate. She imagined that the notes from the pipes would freeze in the air and then fall shattered to the ground like small shards of broken glass. ${ }^{21}$

Her imagery brings to mind the storytelling conceit of Rabelais, who described words which 'congeled in ayre' in intense cold, and could be heard when summer melted them. ${ }^{22}$ On the confines of Rabelais' frozen sea,

Words and cries of men and women froze in the air ... and now, the rigour of winter being over, by the succeeding serenity and warmth of the weather, they melt and are heard. ${ }^{23}$

\section{The audience as food}

In Antarctica, the presence of wildlife is emphatically seasonal, sources of fresh meat are scarce, and emperor penguin breast was once very acceptable tucker. In December 1910, on the second antarctic expedition of Robert Falcon Scott, the young Australian geologist Frank Debenham reported that Christmas dinner was a prolonged business. 'I must give you the Menu', he wrote in his diary - it was mulligatawny soup and fricassee of penguin. ${ }^{24}$

The men of the Scotia expedition who caught emperor penguins for skins and meat were continuing a practice already established on Antarctic expeditions. Bruce, like other naturalists, collected skin, skeletons and other animal

\footnotetext{
21 Laurence Fearnley (1998) 'The Piper and the Penguin', Sport 20 (Autumn): 71-80, p.75, available at www. nzetc.org/tm/scholarly/tei-Ba20Spo-tl-body-d12.html\#name-140994-mention, accessed 27 June 2011.

22 Eugene S McCartney (1953) 'Antiphanes' cold-weather story and its elaboration'. Classical Philology 48(3): 169-72, p. 169.

23 Rabelais in du Chat and others (1807) The works of Francis Rabelais, 4 vols, Lackington, Allen and Co. (and others) London, vol 4 p. 36, available at http://bit.ly/1B0AoVp, accessed 27 February 2012.

24 Quoted in June Debenham, ed (1992) The quiet land - the diaries of Frank Debenham. Bluntisham Books, Huntingdon, p. 32.
} 
specimens for scientific study. His officers and crew used whatever wildlife could be caught as food. Seals and penguins were sometimes the only fresh meat men had in 12 months or more.

The talk of food was constant. Aboard the Scotia, 'it was surprising how often conversation at meals turned towards food: each man had his especial delicacy which he associated with the return to civilisation, and which was unobtainable in our wilderness' ${ }^{25}$

The men killed several emperors the day Bruce photographed Kerr with his bagpipes, and would certainly have taken the breast meat and livers of these animals into their larder. The photographs therefore represent a rare and possibly unique example of a concert in which the performer followed his musical efforts by making a meal of the audience.

\section{After the expedition}

The pipes Kerr had played came to a stirring end. In 1914 Bruce gave them to the First Edinburgh Battalion of the Royal Scots. They were lost in action during the Battle of the Somme. ${ }^{26}$

The ship was commemorated in the name of Scotia Bay in the South Orkney Islands, where the men had wintered, and in the Scotia Sea (and Scotia Ridge) northeast of the Antarctic Peninsula. But despite these names, the Scotia's story - like some others of the time ${ }^{27}$ — has been almost submerged in the wake of the better known voyages of Scott, Shackleton, Amundsen and Mawson. The long-lived photographs of the long-ago piper and his momentary emperor penguin audience are therefore not just an image of two almost cliched subjects, but valuable reminders of a uniquely Scottish expedition to the Far South.

\section{Acknowledgements}

At this paper's presentation at Canberra's School of Music in June 2011, the dancers of the Caledonian Society of Canberra were piped into the hall by Pipes Major Richard Harris of the City of Queanbeyan Pipe Band. Before I spoke, they performed the reel 'The Piper and the Penguin'. ${ }^{28} \mathrm{I}$ was able to arrange this performance through the kindness and coordination of Bill

25 Mossman et al. (1906) The voyage of the 'Scotia', p. 100.

26 Royal Scottish Geographical Society (2012) Images for All website, caption to 'Piper Kerr and emperor penguin', rsgs.org/ifa/gems/polarpenguin.html, accessed 22 February 2012.

27 Nobu Shirase's, for example — see Summerson (this volume).

28 See youtube.com/watch?v=7Ek-_wuz_xk. 
Causbrook and Caledonian Society member Brian Gunning. I thank Richard, Bill, Brian and the Caledonian Society dancers, for their generous willingness to display Scottish culture.

Grateful thanks to Arnan Wiesel of ANU School of Music for devising the conference, and to Rupert Summerson of Canberra for bringing the Hurley quotation and Laurence Fearnley's story to my attention. 
This text is taken from Antarctica: Music, sounds and cultural connections, edited by Bernadette Hince, Rupert Summerson and Arnan Wiesel, published 2015 by ANU Press, The Australian National University, Canberra, Australia. 